\title{
The Determinants of Real Exchange Rate Volatility in Nigeria
}

\author{
Ajao, Mayowa G. Ph.D \\ Dept of Banking and Finance, \\ Faculty of Management Sciences, \\ University of Benin, Benin-City, Edo-State, Nigeria. \\ E-mails:mayourwah@yahoo.com,ajao.mayowa@uniben.edu
}

Igbekoyi, Olushola E., M.sc, $A C A$

\author{
Dept of Accounting, \\ College of Social and Management Sciences, \\ Afe Babalola University, Ado-Ekiti \\ Ekiti-State, Nigeria.
}

Doi:10.5901/ajis/2013.2n1p459

Abstract

The naira exchange rate depreciation and volatility is among the vast macroeconomic maladjustments which have unfolded in the Nigerian economy in the recent past. This paper investigates the determinants of real exchange rate volatility in Nigeria from 198 I through 2008. Having obtained the volatility of exchange rate through the GARCH (I,I) techniques, the ECM was used to examine the various determinants of exchange rate volatility in Nigeria, while the co-integration analysis reveals the presence of a long term equilibrium relationship between REXRVOL and its various determinants. Our empirical analysis further shows that openness of the economy, government expenditures, interest rate movements as well as the lagged exchange rate are among the major significant variables that influence REXRVOL during this period. This study recommends that the central monetary authority should institute policies that will minimize the magnitude of exchange rate volatility while the federal government exercises control of viable macroeconomic variables which have direct influence on exchange rate fluctuation.

Key words: Exchange Rate, Volatility, GARCH, ECM, Co integration JEL Classification: F2I, F3I

\section{Introduction}

Most economies (developed and developing) of the world have experienced high real exchange rate volatility, which translates into high degree of uncertainty in the attainment of major macro-economics and monetary policy objectives in the area of price stability and economic growth. Volatile real exchange rates are associated with unpredictable movements in the relative prices in the economy. Hence, exchange rate stability is one of the main factors influencing foreign (direct and portfolio) investments, price stability and stable economic growth. 
Ever since the breakdown of the Bretton-Woods system in 1973, the exchange rates of many countries have been fluctuating considerably overtime, and there has been more interest in predicting exchange rates. Research related to exchange rate management still remains an area of interest to economists and finance experts, especially in developing countries, despite a relatively enormous body of literature in this area. This is largely because the exchange rate is not only an important relative price of one currency in term of other that connects domestic and world markets for goods and assets, but it also signals the competitiveness of a country's exchange power with the rest of the world in a global market. Besides, it also serves as an anchor which supports sustainable macroeconomic balances in the longrun. There is, therefore, no simple answer to what determine the equilibrium real exchange rate, and estimating the degree of exchange rate volatility and misalignment remains one of the most challenging empirical problems in macroeconomics (Williamson, 1994).

The effect of real exchange rate misalignment on economic decisions has received considerable attention in the literature, not only because of its significant impact on other macroeconomics variables, but also because there has been a number of significant developments in recent time, with substantial contributions being made to both the theory and empirical understanding of exchange rate determination. Important developments in econometrics, together with the increasing availability of high quality data, have also stimulated a large output of empirical work on exchange rate (Botha and Pretorius, 2009).

Exchange rate traditionally played a crucial role in Nigeria monetary policy because of its crucial impact on the country trade relation with other countries, first, as a mono-product (oil) export dependent economy and second, as an import dependent (developing) nation; besides the country's competitiveness and overall economic growth. Therefore, the monetary authorities (Central Bank of Nigeria) on several occasions in recent past had engaged in different exchange rate adjustment policies (fixed and flexible) for the main purpose of attaining the macro-economic objective of price stability. However, in line with major industrial economies, greater flexibility of the exchange rate is much needed to allow the real exchange rate to converge easily with its equilibrium level and to contain the real shocks associated with the transition to a market economy and the depletion of oil production, which is considered to be the main source of external and government revenues.

The fundamental difficulty is that the equilibrium value of the exchange rate is not observable. While the exchange rate volatility refers to a situation in which a country's actual exchange rate deviates from such an unobservable equilibrium, an exchange rate is said to be "undervalued" when it depreciates more than its equilibrium, and "overvalued" when it appreciates more than its equilibrium (Aliyu, 2008). The issue is, unless the "equilibrium" is explicitly specified, the concept of exchange rate volatility remains subjective. There is growing agreement in the literature that prolonged and substantial exchange rate volatility can create severe macroeconomic disequilibria and the correction of external balance will require both exchange rate devaluation and demand management policies. The main intuition behind this is that an increase in exchange rate volatility leads to uncertainty which might have a negative impact on trade flows. Baldwin, Skudelny and Taglioni (2005) discover that effect of exchange rate volatility on trade in the European Union (EU) countries is negative; trade increases as volatility falls and gets progressively larger as volatility approaches zero. While numerous studies were conducted on the extent of naira exchange rate volatility impact on foreign trade in Nigeria (Soludo and Adenikinju, I997; Obaseki, 200 I and Aliyu, 2008), this paper seeks to build on these previous studies by quantitatively measuring the determinants of real exchange rate volatility in Nigeria from I98I to 2008. 


\section{Literature Review}

Currency, like any traded goods, has a price. This price can undergo dramatic changes over a short period of time, as was the case for the Thai baht, which lost $56 \%$ of its value in about six months during the Asian financial crisis in 1997. Alternatively a country's currency may remain stable relative to other currencies over a long period. The explanations for sudden extreme currency volatility or prolonged stability are not always so esoteric. However, an understanding of the factors influencing exchange rate daily is more difficult to come by. The foreign exchange market, with roughly 200 participating countries and US $\$ 2$ trillion in daily turnover is far too complex to be described neatly by a set of theories or formulas (Federal Reserves, 2005). Underscoring the evasiveness of the foreign exchange market, Former U.S. Federal Reserve Board Chairman Alan Greespan once said, "there may be more forecasting of exchange rates with less success than almost any other economic variable."

For decades, the Purchasing Power Parity (PPP) hypothesis has remained a focal point of policy discussions, models and empirical work. the hypothesis postulates an underlying tendency for changes in the nominal exchange rate to be fully offset (at least after some period of time) by changes in the ratio of foreign to domestic price levels. Therefore, even if PPP does not hold at all times, any deviations from it should be eliminated eventually, thus implying that the real exchange rate should be meanreverting (Gelbard and Nagayasu, 2004). Empirical studies have produced little evidence in favour of this hypothesis, and in those that supported it, the speed of convergence of the actual exchange rate to its PPP level has been found to be very low, with half-lives of three years or more (Phylaktis and Kassimatis, 1994; Macdonald, 1995). Such slow convergence has been attributed to nominal price rigidities, either related to price-wage stickiness or to market segmentation and pricing to market policies. A well known blend of PPP with the monetary model contends that, since nominal rigidities prevent a quick adjustment of prices and wages in goods markets, monetary innovations are the cause of the temporary deviations from PPP (Dornbusch, 1976). This view, however, which implies that there should be minimal persistence in the real exchange rate (i.e. it could not follow a random walk), is supported mainly by the analysis of high-inflation episodes, where movements in prices appear to dominate other factors that could lead to deviations from PPP (Zhou, 1997).

There are many factors contributing to real exchange rate volatility. Among these factors are: the level of output, inflation, the openness of an economy, interest rates, domestic and foreign money supply, the exchange rate regime and central bank independence (Stancik, 2007). The degree of the impact of each of these factors varies and depends on a particular country's economic condition. Thus, the countries that are in the transition process (such as Nigeria) are more vulnerable to being affected by these factors, which in turn affect the monetary policy decisions. In a different line of research, attempts were made to model and test for deviation from PPP, as a more permanent phenomenon, by highlighting those real exchange rate movements might be caused by changes on the real side of the economy (Neary, 1988). These models vary depending on the factor that are considered to affect the behaviour of the real exchange rate. Models based on productivity differentials were highlighted by Balasa (1994) and Obstfeld (1993), while Chinn and Johnston (1996) analysed the effect of real interest rate differentials and demand shocks respectively. Exogenous changes in terms of trade have also been found to play an important role in determining the real exchange rate behaviour (Edwards, I994; Ostry 1988). Recently, Juthathip (2009) results for developing Asia showed that real exchange rate is determined by the five key fundamental variables that are medium to long run fundamentals. Productivity differentials, openness, terms of trade, net foreign assets, and government spending. Other variables such as output gap may be included in some countries where such factors play an important role in determining real exchange rate. Moreover, it can be argued that real exchange rates in developing or rapidly transforming countries are likely to be particularly dependent on these real shocks, and that 
the extent to which different shocks affect the behaviour of the real exchange rate depends on countryspecific factors.

In this respect, there is a consensus on the fact that real exchange rate behaviour at medium to long time horizons can at least be partly explained by fundamentals. Ricci, Ferretti and Lee (2008) introduce the Fundamental Equilibrium Exchange Rate (FEER) which considers one of the most broadly used concepts in determining equilibrium real exchange rate. The FEER is defined as the real exchange rate that simultaneously achieves internal and external balances. Internal balance is reached when the economy is at full employment output and operating in a low inflation environment. External balance is characterized as a sustainable balance of payments position over the medium term ensuring desired net flows of resources and external debt sustainability. The FEER tends to abstract from the short-run cyclical and speculative forces in the foreign exchange market.

\section{Exchange Rate Policy in Nigeria}

The most important themes that emerge in the discussion of exchange rates and their management in Nigeria include the high volatility, real exchange rate overvaluation albeit in the context of continuous nominal depreciation, and the search for mechanism for market-determined rate where government is the dominant supplier of foreign exchange. Exchange rate stability is one of the goals of monetary policy in Nigeria, and over the years exchange rate policy has been driven mostly by an obsession to keep the nominal exchange rate 'stable'. For the general public, the health of the economy is gauged by the nominal exchange rate where a depreciating rate is synonymous with a weakening economy. Table I presents some selected exchange rate indices and highlights the extent of distortions in the exchange rate regimes.

Table I: Selected Exchange Rate Indices I980-2008

\begin{tabular}{|l|l|l|l|l|l|}
\hline Period & $\begin{array}{l}\text { Nominal } \\
\text { Exch. Rate } \\
\text { N to US\$I }\end{array}$ & $\begin{array}{l}\text { Nominal Eff. } \\
\text { Exchange Rate } \\
\text { (I985=I00) }\end{array}$ & $\begin{array}{l}\text { Nominal } \\
\text { Exchange Rate } \\
\text { Premium (\%) }\end{array}$ & $\begin{array}{l}\text { Real Effective } \\
\text { Exchange Rate } \\
\text { (I985=I00) }\end{array}$ & $\begin{array}{l}\text { Parallel } \\
\text { Market } \\
\text { Exchange Rate }\end{array}$ \\
\hline I980-I985 & 0.70 & 108.27 & I64.24 & 87.81 & 1.97 \\
I986-I990 & 5.20 & 19.24 & 41.22 & 100.86 & 6.91 \\
I99I-I995 & I8.6I & 3.32 & II4.73 & 89.66 & 42.73 \\
I996-I999 & 21.89 & 0.80 & 289.78 & I40.50 & 85.31 \\
2000-2008 & I05.50 & 0.20 & 9.83 & 79.95 & II4.3I \\
\hline
\end{tabular}

Source: Central Bank of Nigeria, Annual Report and Statement of Accounts, various issues

Another key feature of the exchange rate regime is the huge premium which indicates the extent of distortions in the market. This has been due to the fixed regime until the mid I980s, the managed float of the SAP era, the re-fixing of the official rate during the Abacha regime (1994-1998) and thus the large disparity between the official and the parallel (free) market rates. Given the huge demand for foreign exchange for imports and sundry reasons, and also the fact that forex at the official rate was rightly regulated with strict documentation requirements, the parallel market boomed (Soludo, 2008).

Real exchange rate (RER) volatility is another feature of the regime. The standard deviation in real exchange rate growth for I96I-70 was 4 per cent. For the period I99I-2000 - a period of greater liberalization, the standard deviation was 35 per cent, with Nigeria having one of the most volatile RER regimes among developing countries. The RER was more stable during the fixed nominal exchange rate regime (I96I-1985), and wide volatility started with the emergence of major oil earnings and fiscal imprudence, surging domestic price inflation, and futile efforts to manage the nominal exchange rate. 
RER uncertainty (proxied by volatility) is of major concern because it inhibits private sector investment.

A critical issue faced by policymakers is how to avoid RER overvaluation and exchange rate premia through a market determined nominal exchange rate regime, especially where the government is the major supplier of foreign exchange. The Central Bank tried all manner of experiments in determining the official nominal rate which is essentially a managed float. Between 1999 and 200I, the CBN reverted to the pre-reform system of selling foreign exchange in the interbank foreign exchange market (IFEM) at a predetermined rate, and the interbank market split into the IFEM and the open inter-bank market where banks traded among themselves at freely negotiated exchange rates (the NIFEX). The Bureau de Change and the parallel market for foreign exchange constitute the free markets - where no documentations are required for transactions in foreign exchange. In 2000, the exchange rate depreciated in all markets. At the IFEM, the Naira depreciated on the average by 6.5 per cent to NIOI.65 to one US\$. This was caused principally by a significant increase in import-driven demand for foreign exchange following the increased government expenditures: total demand for foreign exchange at the IFEM during the year was $\$ 6.9$ billion compared with $\$ 4.9$ billion in 1999 . The parallel market depreciated by 30 percent between December 1999 and May 200I, and the differential with the IFEM rate widened to 20 percent. Following the excess liquidity triggered off by fiscal expansion, a foreign exchange 'crisis' emerged in April 200I when the CBN made a small adjustment of the IFEM rate before it had effectively mopped up the excess liquidity. The government sold large amounts of foreign exchange to deal with the crisis thereby depleting foreign reserves. As a consequence of this measure and other tighter monetary policy measures, the parallel market exchange rate appreciated from NI40 to an average of NI33 throughout the remainder of 200I, with the gap between the official and parallel market rates at 2 I percent. In 2002, the Central Bank reintroduced the Dutch Auction System (DAS) a system which had been tried at the introduction of SAP in the mid 1980s but which later collapsed. Since the current civilian government abolished the fixed (nominal) exchange rate of the Abacha era, the premium between the parallel and the official rates fell sharply from 28.98 per cent to only 9.83 per cent. With the introduction of the DAS, the premium has further reduced to about 7.8 per cent. This is still high compared to the rates in many other developing countries where they are below 2 per cent. Hopefully, the DAS (if allowed to stay and work properly) could significantly reduce or eliminate the exchange rate premium. But the obsession with the stability of the nominal exchange rate by policymakers is a possible constraint in allowing the rate to find its true market value (Soludo, 2008).

Based on the recent developments in exchange rate policy in Nigeria, the average rate of the naira to US appreciated with an average rate of \#I28 to a dollar at Dutch Auction System (DAS) in 2006. Exchange rate was generally stable from 2006 until December 2008. Stability and mild appreciation was sustained throughout 2007 and most of 2008 due to large foreign exchange inflows and deliberate policy not to allow rates to appreciate massively, thereby accumulating huge reserves. For the first time there was a convergence of rate among various segments of the foreign exchange market. The exchange rate regime will continue to be a key shock absorber for the economy to keep internal and external balance (Soludo, 2009).

\section{Data and methodology}

\section{I Data and the Explanatory Variables}

The following key variables have been found to play a theoretical key role in explaining the movement of real exchange rate. These determinants variables vary between economies according to economic and financial conditions of each economy. 


\section{Table II: Definitions and Sources of Variables used in Regression Analysis}

\begin{tabular}{|l|l|l|}
\hline Variable & Definition and Construction & Source \\
\hline Nominal Exchange Rate & $\begin{array}{l}\text { Bilateral Exchange rate of Nigeria } \\
\text { Naira to US Dollar }\end{array}$ & $\begin{array}{l}\text { Central Bank of } \\
\text { Nigeria (CBN) }\end{array}$ \\
\hline Real Exchange Rate & $\begin{array}{l}\text { Nominal Exchange Rate/Consumer } \\
\text { Price Index }\end{array}$ & CBN \\
\hline $\begin{array}{l}\text { Volatility of Nominal } \\
\text { Exchange Rate }\end{array}$ & $\begin{array}{l}\text { Standard Deviation of the log } \\
\text { differences of real exchange rate }\end{array}$ & CBN \\
\hline Productivity & Real Gross Domestic Product & CBN \\
\hline Trade Openness & OPN =Import+Export/Real GDP & CBN \\
\hline Government Expenditure & $\begin{array}{l}\text { Government total expenditure } \\
\text { (recurrent and capital) }\end{array}$ & CBN \\
\hline Real Interest Rate & $\begin{array}{l}\text { Prime Lending Rate/Consumer Price } \\
\text { Index }\end{array}$ & CBN \\
\hline Money Supply & Total Monetary Liabilities $\left(\mathrm{M}_{2}\right)$ & $\mathrm{CBN}$ \\
\hline
\end{tabular}

Source: Authors' compilation

\section{Empirical Design}

\section{(a) Volatility Estimate}

This study focused on the determinants of real exchange rate volatility in Nigeria. The frequency of data is kept at annual level with the time scope taken from I98I to 2008. Having generated the real exchange rate from the nominal exchange rate, we derived the real exchange rate volatility (REXRVOL) with the aid of the Generalised Autoregressive Conditional heteroskedasticity (GARCH I, I) which belong to the family of ARCH 'as introduced by Engle (1982) and Bollerslev (1986). The jointly estimated GARCH $(\mathrm{I}, \mathrm{I})$ model is given as:

$$
\sigma_{t}^{2}=\alpha_{0}+\alpha_{1} \Sigma_{t-1}^{2}+\beta \sigma_{t-1}^{2}+\mu_{t}
$$

Which says that the conditional variance $\left(\sigma^{2}\right)$ of $\Sigma$ at time $t$ depends not only on the squared error term in the previous time period (as in $\mathrm{ARCH}(\mathrm{I})$ ) but also on its conditional variance in the previous time period.

\section{(b) Stationarity Test:}

Since the data used in this study are time series, there is need to check the stationarity of the data. The stationarity properties of our data was checked using the Augmented Dickey Fuller (ADF) test (Dickey and Fuller 1979, I98I) and the Phillips Perron (PP) test (Phillips and Perron, I988). The general form of these tests is estimated in the following forms:

$$
\Delta \mathrm{Y}_{\mathrm{t}}=\mathrm{b}_{0}+\beta \mathrm{Y}_{\mathrm{t}-\mathrm{I}}+\mu_{\mathrm{I}} \Delta \mathrm{Y}_{\mathrm{t}-\mathrm{I}}+\mu_{2} \Delta \mathrm{Y}_{\mathrm{t}-2}+\ldots+\mu_{\mathrm{p}} \Delta \mathrm{Y}_{\mathrm{t}-\mathrm{p}}+\mathrm{e}_{\mathrm{t}} \ldots \ldots \ldots \ldots \ldots \ldots \text { (ii) }
$$

Where $Y_{t}$ represents time series to be tested, $b_{0}$ is the intercept term, $\beta$ is the coefficient of interest in the unit root test, $\mu$ is the parameter of the augmented lagged first difference of $Y_{t}$ to represent the $p$ th order autoregressive process and $\boldsymbol{e t}$ is the white noise error term. 


\section{(c) Cointegration Analysis:}

In order to solve the spurious regression problem and violation of the assumptions of the classical regression model; cointegration analysis was used to examine the longrun relationship between real exchange rate volatility (REXRVOL) and its various determinants. As part of the empirical design the basic estimating equation is specified as follows:

\section{$R E X R V O L=\alpha_{0}+\alpha_{I} G E X P+\alpha_{2} M S+\alpha_{3} O P N+\alpha_{4} P R O D+\alpha_{5} R E X R+\alpha_{6} R I N T R+$

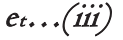

Where REXRVOL is the Real Exchange rate volatility, GEXP is the government expenditure, MS is money supply, OPN is the openness of the economy, PROD is the productivity index, REXR is the Real exchange rate, RINTR is the Real interest rate while et is the stochastic error term. To test for cointegration in order to know the disequilibrium error, equation (iii) is rewritten as:

$e_{t}=R E X V O L-\alpha_{o}-\alpha_{I} G E X P-\alpha_{2} M S-\alpha_{3} O P N-\alpha_{4} P R O D-\alpha_{5} R E X R-\alpha_{6} R I N T$

(iv)

The presence of cointegration is tested using the Johansen (1988) approach. In this method, the number of cointegrating relations is tested on the basis of trace statistics and maximum Eigen statistics. Once the presence of cointegration is established, we estimate an error correction model (ECM) that includes both the longrun and short run dynamics. Then the disequilibrium errors in equation (iv) form a stationarity time series and have a zero mean, the et should be stationary, $\mathrm{I}(0)$ with $\Sigma($ et $)=0$. The longrun equilibrium may be rarely observed but there is a tendency to move towards equilibrium. Thus, Error Correction Model (ECM) is used to represent the longrun (static) and shortrun (dynamic) relationships between REXRVOL and other variables. Accordingly ECM is suitable to estimate the effect of other variables on REXRVOL. Besides, the purpose of ECM model is to indicate the speed of adjustment from the short run equilibrium to the long run equilibrium state. The greater the coefficient of the parameter, the higher the speed of adjustment of the model from short run to long run. Considering our base equation (iii), the ECM model is specified as follows: Thus, equation (v) represents the error correction model

$$
\begin{gathered}
\triangle R E X R V O L=\alpha_{0}+\alpha_{1} \sum_{t=1}^{n} \Delta G E X P_{t-1}+\alpha_{2} \sum_{t=1}^{n} \Delta M S_{t-1}+\alpha_{3} \sum_{t=1}^{n} \Delta O P N_{t-1}+\alpha_{4} \sum_{t=1}^{n} \Delta P R O D_{t-1}+ \\
\alpha_{5} \sum_{t=1}^{n} \Delta R E X R_{t-1}+\alpha_{6} \sum_{t=1}^{n} \Delta R I N T R_{t-1}+\delta E C M(-1)+\varepsilon t \ldots \ldots \ldots \ldots \ldots \ldots \ldots . . .(v)
\end{gathered}
$$

Where $\varepsilon t$ is the error term, ECM (-I) is the error correction term, $\delta$ captures the long run impact. The short run effects are captured through the individual coefficients of the differenced terms $(\alpha)$ while the coefficient of the ECM variable contains information about whether the past values of variables affect the current values. The size and statistical significance of the coefficient of the ECM measure the tendency of each variable to return to the equilibrium. A significant coefficient implies that past equilibrium errors play a role in determining the current outcomes.

\section{Results and findings}


Since the application of cointergration technique requires that all the variables should be integrated of the same order, we start the analysis by examining the unit root properties of the variables. The result of both methods (ADF and PP tests) as shown in Table III shows that GEXP, MS and PROD are stationary at level under both methods while OPN, REXR and RINTR are non-stationary at level under both method. As a result, all the variables have been differenced once to check their stationarity. At first differencing the calculated ADF and PP test statistics clearly reject the null hypothesis of unit root when compared with their corresponding critical values hence the ADF and PP tests decisively confirm stationarity of each variable at first difference and depict the same order of integration I (I) behaviour. Thus we can apply Johansen cointegration approach to examine the long run relationship among the variables.

\section{Table III: Stationarity Test of the Variables}

\begin{tabular}{|c|c|c|c|c|}
\hline \multirow[t]{2}{*}{ Variable } & & \multicolumn{2}{|c|}{ Unit Root Tests } & \multirow[t]{2}{*}{ Conclussion } \\
\hline & & $\mathrm{ADF}$ & PP & \\
\hline \multirow[b]{2}{*}{ GEXP } & Level & $6.456987^{\text {* }}$ & $7.75195^{\text {t* }}$ & \multirow{2}{*}{$\mathrm{I}(\mathrm{I})$} \\
\hline & First Diff & $2.77759 I^{\prime}$ & -3.01527 & \\
\hline \multirow[b]{2}{*}{ MS } & Level & $6.595822^{*}$ & $9.51936^{*}$ & \multirow{2}{*}{$\mathrm{I}(\mathrm{I})$} \\
\hline & First Diff & $4.709117^{* *}$ & $8.00283^{\text {* }}$ & \\
\hline \multirow[b]{2}{*}{ OPN } & Level & $2.02718 \mathrm{I}$ & $4.923353^{\text {* }}$ & \multirow{2}{*}{$\mathrm{I}(\mathrm{I})$} \\
\hline & First Diff & $-4.63518^{\text {* }}$ & $-4.63112^{* x}$ & \\
\hline \multirow[b]{2}{*}{ PROD } & Level & I.5II465 & $3.4 \mathrm{II} 539$ & \multirow{2}{*}{$\mathrm{I}(\mathrm{I})$} \\
\hline & First Diff & 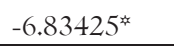 & $-6.8253 I^{*}$ & \\
\hline \multirow[b]{2}{*}{ REXR } & Level & -2.16613 & -2.29462 & \multirow{2}{*}{$\mathrm{I}(\mathrm{I})$} \\
\hline & First Diff & $-4.61502^{\text {* }}$ & $-4.61624^{*}$ & \\
\hline \multirow[b]{2}{*}{ RINTR } & Level & $-\mathrm{I} .86364$ & $-\mathrm{I} .5949 \mathrm{I}$ & \multirow{2}{*}{$\mathrm{I}(\mathrm{I})$} \\
\hline & First Diff & -3.23366 & $-8.93096^{*}$ & \\
\hline \multirow{3}{*}{ Critical Value } & $\mathrm{I} \%$ & $-3.77 \mathrm{II} 46$ & -3.69987 & \\
\hline & $5 \%$ & -2.98104 & -2.97626 & \\
\hline & $10 \%$ & $-2.6299 \mathrm{I}$ & -2.62742 & \\
\hline
\end{tabular}

NB: \&epresent significant at I\%, 5\% and I0\% respectively

Source: Author's computation

The cointegration results are given in table IV and V. From these tables, it can be observed that the trace statistics and maximum eigen values are greater than the critical values at $5 \%$ significant level; while we have four cointegrating factors in the trace statistics, we have two cointegrating factors in the maximum eigen values. Hence we reject the null hypothesis that there is no cointegration relationship among these variables. In other words, there is unique long run equilibrium relationship among GEXP, MS, OPN, REXR and RINTR. 
Table IV: Unrestricted Cointegration Rank Test (Trace)

\begin{tabular}{|l|l|l|l|l|}
\hline Hypothesized & & Trace & 0.05 & \\
\hline No. of CE(s) & Eigenvalue & Statistic & Critical Value & Prob.* \\
\hline & & & & \\
\hline None * & 0.980929 & 224.6661 & 125.6154 & 0 \\
\hline At most I * & 0.804045 & 121.7165 & 95.75366 & 0.0003 \\
\hline At most $2^{*}$ & 0.681087 & 79.33992 & 69.81889 & 0.0072 \\
\hline At most $3^{*}$ & 0.58692 & 49.62613 & 47.85613 & 0.0338 \\
\hline At most 4 & 0.529047 & 26.63916 & 29.79707 & 0.1108 \\
\hline At most 5 & 0.237446 & 7.06122 & 15.49471 & 0.5705 \\
\hline At most 6 & 0.000503 & 0.013086 & 3.841466 & 0.9087 \\
\hline
\end{tabular}

Trace test indicates 4 cointegrating eqn(s) at the 0.05 level

* denotes rejection of the hypothesis at the 0.05 level

MacKinnon-Haug-Michelis (I999) p-values

Table V: Unrestricted Cointegration Rank Test (Maximum Eigenvalue)

\begin{tabular}{|l|l|l|l|l|}
\hline Hypothesized & & Max-Eigen & 0.05 & \\
\hline No. of CE(s) & Eigenvalue & Statistic & Critical Value & Prob. \\
\hline & & & & \\
\hline None * & 0.980929 & 102.9496 & 46.23142 & 0 \\
\hline At most I * & 0.804045 & 42.37657 & 40.07757 & 0.0271 \\
\hline At most 2 & 0.681087 & 29.71379 & 33.87687 & 0.145 \\
\hline At most 3 & 0.58692 & 22.98697 & 27.58434 & 0.174 \\
\hline At most 4 & 0.529047 & 19.57794 & 21.13162 & 0.0813 \\
\hline At most 5 & 0.237446 & 7.048134 & 14.2646 & 0.4835 \\
\hline At most 6 & 0.000503 & 0.013086 & 3.841466 & 0.9087 \\
\hline
\end{tabular}

Max-eigenvalue test indicates 2 cointegrating eqn(s) at the 0.05 level

* denotes rejection of the hypothesis at the 0.05 level

MacKinnon-Haug-Michelis (I999) p-values

The main output from ECM estimation is divided into two sections as shown in Table IV, the upper part provides the standard output of the mean equation, while the lower part contains the coefficients of variance equation. The lower part of the output indicate that the sum of the ARCH parameters correspond to $\alpha_{I}$ and the GARCH parameters correspond to $\beta$ is very close to one, as shown in equation I above, indicating that the volatility shocks of Nigeria real exchange rate are quite persistence. The long run coefficients of the determining variables have different signs and magnitude in term of relationships with REXRVOL. DGEXP positively influence REXRVOL and is also significant, 
DOPN was although significant determinant of REXRVOL but has a negative impact on REXRVOL. Also DREXR (-I) has a positive and significant relationship with REXRVOL, while DRINTR has a negative but significant impact on REXRVOL during this period. Among all the explanatory variables, Money Supply (DMS) and Productivity Index (DPROD) are found to be statistically insignificant determinant of REXRVOL so in explaining the shocks of real exchange rate volatility in Nigeria, Money Supply by Central Bank of Nigeria and the indices of the productive sectors cannot be considered relevant in terms of magnitude and directions during the period covered by this study.

The result of ECM as given in Table VI indicates that the model seems to be good as it satisfies the diagnostic test and also has a high Adjusted R-Squared $\left(\mathrm{AR}^{2}\right)$ value of 0.803 , which indicate that only about $20 \%$ of the total systematic variation in REXRVOL is not accounted for by the explanatory variables all taken together. The Durbin Watson (DW) statistics value of 2.206 shows that there is no serious problem of serial correlation and heteroskedasticity. The error term is also found to be normally distributed. The coefficient of the error correction term with one period lag $[\mathrm{ECM}(-\mathrm{I})]$ is negative as expected with a value of -0.592793 and is also statistically significant in terms of its associated Z-value $(-4.168728)$. This signify that the long run relationship of the estimated model is stable and any disequilibrium created in the short run will be temporary and will get corrected over a period of time.

\section{Table VI: Error Correction Model (ECM) Results}

\begin{tabular}{|c|c|c|c|c|}
\hline \multicolumn{5}{|c|}{$\begin{array}{l}\text { Dependent Variable: DREXRVOL } \\
\text { GARCH }=\mathrm{C}(\mathrm{I} 6)+\mathrm{C}(\mathrm{I} 7)^{*} \mathrm{RESID}(-\mathrm{I})^{\wedge} 2+\mathrm{C}(\mathrm{I} 8)^{*} \mathrm{GARCH}(-\mathrm{I})\end{array}$} \\
\hline Variable & Coefficient & Std. Error & z-Statistic & Prob. \\
\hline $\mathrm{C}$ & -0.028844 & 0.014176 & -2.034683 & 0.0419 \\
\hline DREXRVOL(-I) & 0.464569 & 0.336875 & I.379054 & 0.1679 \\
\hline DGEXP & 0.000593 & 0.000191 & 3.101569 & 0.0019 \\
\hline $\operatorname{DGEXP}(-\mathrm{I})$ & $-3.69 \mathrm{E}-05$ & 0.000186 & -0.199138 & 0.8422 \\
\hline DMS & $-3.15 \mathrm{E}-08$ & 8.49E-08 & -0.371117 & 0.7106 \\
\hline $\operatorname{DMS}(-\mathrm{I})$ & $-9.72 \mathrm{E}-08$ & I.53E-07 & -0.63555 & $0.525 \mathrm{I}$ \\
\hline DOPN & -0.026044 & 0.006353 & -4.099603 & 0 \\
\hline $\operatorname{DOPN}(-\mathrm{I})$ & 0.007663 & 0.00816 & 0.939165 & 0.3476 \\
\hline DPROD & $-7.79 \mathrm{E}-07$ & 7.70E-07 & -1.011673 & 0.3117 \\
\hline $\operatorname{DPROD}(-\mathrm{I})$ & 4.46E-07 & 9.8IE-07 & $0.45490 \mathrm{I}$ & 0.6492 \\
\hline DREXR & -0.040407 & 0.03021 & -1.337526 & 0.1811 \\
\hline $\operatorname{DREXR}(-\mathrm{I})$ & 0.139827 & 0.030656 & 4.561107 & 0 \\
\hline DRINTR & -0.034093 & 0.010115 & -3.370696 & 0.0007 \\
\hline $\operatorname{DRINTR}(-\mathrm{I})$ & 0.000293 & 0.019594 & 0.014932 & $0.988 \mathrm{I}$ \\
\hline $\operatorname{ECM}(-\mathrm{I})$ & -0.592793 & $0.38208 \mathrm{I}$ & -4.168728 & 0 \\
\hline
\end{tabular}




\begin{tabular}{|l|l|l|l|l|}
\hline \multicolumn{5}{|c|}{ Variance Equation } \\
\hline C & 0.000196 & 0.001669 & 0.117614 & 0.9064 \\
\hline RESID(-I)^2 & 0.144545 & 0.667087 & 0.21668 & 0.8285 \\
\hline GARCH(-I) & 0.599974 & 2.379858 & 0.252105 & 0.801 \\
\hline & & & & \\
\hline R-squared & 0.913481 & Mean dependent var & & -0.004777 \\
\hline Adjusted R-squared & 0.803366 & S.D. dependent var & & 0.089283 \\
\hline S.E. of regression & 0.039591 & Akaike info criterion & & -3.05699 \\
\hline Sum squared resid & 0.017242 & Schwarz criterion & & -2.186 \\
\hline Log likelihood & 57.74087 & Hannan-Quinn criter. & & -2.806176 \\
\hline Durbin-Watson stat & 2.206272 & & & \\
\hline Source:Author'scompution & & \\
\hline
\end{tabular}

Source: Author's computation

\section{Conclussion}

Exchange rate shocks and instability is a common feature of emerging economies especially the import dependent one like Nigeria, this is because there will always be an increasing demand for foreign currencies in exchange for imported goods by the teeming populace. It is in this perspective that this paper seeks to examine the determinants of real exchange rate volatility in Nigeria using the Generalised Autoregressive Conditional Heteroskedasticity $(\mathrm{GARCH})$ and Error Correction Model. Based on the extant literatures, we identify relevant variables that influence real exchange rate volatility (Government Expenditure, Money Supply, Real interest rate, productivity index and openness of the economy), which we include in our model estimation.

The empirical results of the cointegration analysis shows that there is long run equilibrium relationship among the variables, while our error correction model coefficients from the estimated short run dynamic model showed reasonable speed of adjustment towards the long run equilibrium. Analyzing the direction and magnitude of the explanatory variable coefficients, we observed that government expenditure, openness of the economy, real exchange rate and real interest rate are significant determinants of real exchange rate volatility during the period I98I-2008, though they all have different magnitude of influence on the volatility of exchange rate. While money supply and productivity index have no significant influence on real exchange rate volatility during this period. These findings is partly consistent with the findings of Aliyu (2008); and Al-Samara (2009) who investigated the determinant of exchange rate volatility in Nigeria and Syrian economy respectively.

The strive by central monetary authority to ensure a stable exchange rate regime and policy will continue to exist as there continue to be openness of Nigerian economy to foreign trade especially as an import dependent economy. Therefore this paper recommends that the monetary authority should institute a policy that will ensure the limit within which exchange rate can fluctuate within a given time period. Besides, government should exercise direct control of viable macroeconomic variables (inflation rate, interest rate and GDP) which have direct influence on exchange rate. Success in this regard will further limit the fluctuation of exchange rate in the economy. 


\section{References}

Aliyu, S.U.R. (2008). Exchange Rate Volatility and Export Trade in Nigeria: An Empirical Investigation. An MPRA Paper No.13490.

Al-Samara, M. (2009). "The Determinants of Real Exchange Rate Volatility in the Syrian Economy" Centre d'Economie de la sarbonne, universite Paris.

Balassa, B. (1964). "The Purchasing Power Parity Doctrine: A Reappraisal". Joutnal of Political Economy72(6) 584-596.

Baldwin, R., Skudelny, F. and Taglioni, D. (2005) "Trade Effect of the Euro: Evidence from Sectoral Data." European Central Bank Working Paper Series (February) No.446.

Bollerslev, T. (1986) Generalised Antrogressive Conditional Heteroscedasticity. Journal of Econometric. 31: 307327

Botha, I. and Pretorius M. (2009) "Forecasting the Exchange Rate in South Africa: A Comparative Analysis Challenging the Random Walk Model." African Journal of Business Management. 3(9) 486-494.

Chinn, M. and Johnston, L. (1996) "Real Exchange Rates, Productivity and Demand Shocks: Evidence from a Panel of I4 Countries" National Bureau of Economic Research (NBER) Working Paper 5709 Cambridge, Mass.

Dickey, D.A. and Fuller, W.A. (1979) "Distribution of the Estimators for Autoregressive Time Series with Unit Root". Journal of American Statistical Association. 74:427-43I.

Dickey, D.A. and Fuller, W.A. (198I) "Likelihood Ratio Statistics for Autoregressive Time Series With a Unit Root" Econometrica 49: 1057-1072.

Dornbusch, R. (1976) "Expectations and Exchange Rate Dynamics" Journal of Political Economy 84(6) II6III76.

Edwards, S. (1989). Real Exchange Rate, Devaluation and Adjustment. The MIT Press, Cambridge.

Engle, R.F. (1982) Autoregressive Conditional Heteroscedasticity with Estimates of the Variance of United Kingdom Inflation, Econometrica. 50:987-1008

Federal Reserves (2005) "Federal Reserve Statistical Release - Foreign Exchange Rates" U.S. Federal Reserve website; http://www.federalreserve.gov/releases/HIO/Hist/ accessed November 2005.

Gelbard, E. and Nagayasu, J. (2004). "Determinants of Angola’s Real Exchange Rate, 1992-\2002" The Developing Economies XLII (3), 392-404.

Hau, H. (2002). "Real Exchange Rate Volatility and Economic Openness: Theory and Evidence". Journal of Money, Credit and Banking. 34(3) 6II-630.

Imed, D. and Christophe R. (200I). "The long-run determinants of real exchange rate: New evidence based on Panel data, Unit root and Cointegration tests for MENA countries," Sorbonne University.

Juthathip, J. (2009). "Equilibrium Real Exchange Rate Misalignment and Export Performance in Developing Asia" ADB Economics, Working Paper No.I5.

MacDonald, R. (1995). "Long-run Exchange Rate Modeling: A Survey of the Recent Evidence." IMF Staff Papers 42(3): 437-489.

Neary, P. (1988). "Determinants of the Equilibrium Real Exchange Rate" American Economic Review.78(I) 2I0-2I5.

Obaseki, P.J. (2002) "The Purchasing Power Parity (PPP) Measure of Naira's Equilibrium Exchange Rate" CBN Economic and Financial Review 36 (I) I-2I.

Obstfeld, M. (1993). "Model Trending Real Exchange Rate" Centre of International and Development Economics Research, Working Paper C93-0I I, Berkeley California, University of California.

Phillips, P.C.B and Perron, P. (1988) "Testing for a Unit Root in Time Series Regressions" Biometrica LXXV: 335-35I.

Phylaktis, K. and Kassimatis, Y. (1994). "Does the Real Exchange Rate Follow a Random Walk? The Pacific Basin Perspective". Journal of International Money and Finance I3(4) 476-495.

Ricci, L.A., Forretti, G.M. and Lee, J. (2008). "Real Exchange Rate and Fundamentals: A Cross- Country Perspective", IMF Working Paper. 
Soludo, C.C. (2008) "Nigeria: Macroeconomic Assessment and Agenda for Reforms". Being a Publication of African Institute for Applied Economics

Soludo, C.C. and Adonikinji, A.F. (1997) "Exchange Rate Misalignment and Investment in Nigeria” Being a Paper presented to OECD Development Centre, Paris.

Stancik, J. (2007). "Determinants of Exchange Rate Volatility: The Case of the New EU Members' Czech Journal of Economics and Finance. 57(9\&I0) 56-72.

Williamson, J. (1994) "Estimates of FEERs" in Estimating Equilibrium Exchange Rate by J. Williamson (ed): Washington, Institute of International Economics.

Zhou, S. (1997). "Purchasing Power Parity in High-Inflation Countries: A Cointegration Analysis of Integrated Variables with Trend Breaks". Southern Economic Journal. 64(2) 450-467 